\title{
Cyclone hazard proneness of districts of India
}

\author{
M MOHAPATRA \\ Cyclone Warning Division, India Meteorological Department, Mausam Bhawan, Lodi Road, \\ New Delhi 110 003, India. \\ e-mail: mohapatraimd@gmail.com
}

\begin{abstract}
Hazards associated with tropical cyclones (TCs) are long-duration rotatory high velocity winds, very heavy rain, and storm tide. India has a coastline of about $7516 \mathrm{~km}$ of which $5400 \mathrm{~km}$ is along the mainland. The entire coast is affected by cyclones with varying frequency and intensity. Thus classification of TC hazard proneness of the coastal districts is very essential for planning and preparedness aspects of management of TCs. So, an attempt has been made to classify TC hazard proneness of districts by adopting a hazard criteria based on frequency and intensity of cyclone, wind strength, probable maximum precipitation, and probable maximum storm surge. Ninety-six districts including 72 districts touching the coast and 24 districts not touching the coast, but lying within $100 \mathrm{~km}$ from the coast have been classified based on their proneness. Out of 96 districts, 12 are very highly prone, 41 are highly prone, 30 are moderately prone, and the remaining 13 districts are less prone. This classification of coastal districts based on hazard may be considered for all the required purposes including coastal zone management and planning. However, the vulnerability of the place has not been taken into consideration. Therefore, composite cyclone risk of a district, which is the product of hazard and vulnerability, needs to be assessed separately through a detailed study.
\end{abstract}

\section{Introduction}

Tropical Cyclones (TCs) are one of the natural hazards that affect India almost every year causing huge losses of lives and property. The term 'Cyclone' is used globally to cover tropical weather systems (World Meteorological Organisation (WMO), 2009), in which winds equal or exceed the minimum of 34 knot $(62 \mathrm{kmph})$. These are intense low pressure systems of the earth atmosphere coupled system and are extreme weather events of the tropics. TCs are known by many names the world over like cyclones, typhoons, hurricanes, etc. Though TCs differ by name across regions, they are classified according to associated maximum sustained surface wind speed (MSW). The classification, however, varies from region to region. The Indian classification of these intense low pressure systems (India Meteorological Department (IMD), 2013) is shown in table 1. The low pressure systems with intensity of depression and above are known as cyclonic disturbances.

India has a coastline of about $7516 \mathrm{~km}$ of which $5400 \mathrm{~km}$ is along the mainland. The entire coast is affected by TCs with varying frequency and intensity. Although the North Indian Ocean (the Bay of Bengal and Arabian Sea) generates only about $7 \%$ of the world's TCs (5-6 TC's per year according to IMD (2013)), their impact is comparatively high and devastating, especially when they strike the coasts bordering the north Bay of Bengal. Thirteen coastal states and Union Territories (UTs) in the country are affected by TCs. Four states (Tamil Nadu, Andhra Pradesh, Odisha and West Bengal) and one UT (Puducherry) on the east coast and

Keywords. Tropical cyclone; hazard; India; district.

J. Earth Syst. Sci. 124, No. 3, April 2015, pp. 515-526

(C) Indian Academy of Sciences 
Table 1. Indian classification of cyclonic disturbances in the North Indian Ocean (Bay of Bengal and Arabian Sea).

\begin{tabular}{llc}
\hline Type & $\begin{array}{c}\text { Wind speed } \\
(\mathrm{kmph})\end{array}$ & $\begin{array}{c}\text { Wind speed } \\
(\mathrm{knot})\end{array}$ \\
\hline Low pressure area (L) & $<31$ & $<17$ \\
Depression (D) & $31-49$ & $17-27$ \\
Deep depression (DD) & $50-61$ & $28-33$ \\
Cyclonic storm (CS) & $62-88$ & $34-47$ \\
Severe cyclonic storm (SCS) & $89-118$ & $48-63$ \\
Very severe cyclonic storm (VSCS) & $119-221$ & $64-119$ \\
Super cyclonic storm (SuCS) & 222 or more & 120 or more \\
\hline
\end{tabular}

Note: Generic names like tropical cyclone or cyclone is used to represent CS, SCS, VSCS and SuCS as a whole.

one state (Gujarat) on the west coast are more vulnerable to TC hazards (Mohapatra et al. 2012). Hazards associated with TC are long duration rotatory high velocity winds, very heavy rain, and storm tide (the combined effect of stormsurge and astronomical tide). Out of these, the storm surge is the greatest killer hazard associated with TC (Dube et al. 2013). The detailed damage potential of TCs is given in 'Damage Potential of Cyclones' published by IMD (2002). It is being used by IMD to mention the 'expected damages and suggested actions by the disaster managers' in its three hourly bulletins issued during the period of TC.

The IMD is the nodal government agency that provides weather services related to TCs in India (IMD 2013). IMD has identified the districts for which cyclone warnings are issued (Mohapatra et al. 2012). For the purpose of better TC disaster management in the country, it is necessary to define TC proneness and identify TC prone coastal districts. It is also necessary to decide degree of hazard proneness of a district by considering TC parameters so that mitigation measures are prioritized.

There have been many attempts to define districtwise hazard proneness. The Building Materials \& Technology Promotion Council (BMTPC) of Ministry of Urban Development, Government of India, identified TC prone districts of India by taking into consideration TC hazards of the coastal districts (BMTPC 2006), which is a modification of the earlier edition of 1997. These districts are also listed in cyclone guidelines published by National Disaster Management Authority (NDMA), Government of India (NDMA 2008). These lists include some inland districts of a few states in northeast India, which do not experience the full impact of TC. Also, while preparing such a list, no weightage was given to the number as well as intensity of TCs crossing the coast as the Vulnerability Atlas published by BMTPC does not distinguish between the cyclonic wind and the wind due to other phenomena like thunder squall, etc. As a result, it gives almost uniform weight to all the districts in the coast. The wind speed as depicted in BMTPC atlas is based on IS: 875 (part 3): 1987 (1989) and TC data of 1877-2005, IMD, Government of India, as given in the footnotes of the map. Hence, it does not take into consideration the acual/estimated wind speed experienced in a district during a TC. Spatially also, it does not represent the data for each district due to limited data used for the calculation of basic wind speed.

There have been many studies on calculation of storm surge based on nomograms prepared by IMD and the dynamical storm surge model developed by Indian Institute of Technology, Delhi (Dube et al. 2013). Attempts have been made in the BMTPC atlas to develop districtwise probable maximum storm surge (PMSS). Details have been reviewed by Kalsi et al. (2007). The calculation of PMSS in the BMTPC atlas has taken into consideration maxim past recorded storm surge for the districts and simulation studies using IIT Delhi model (Dube et al. 2013).

Estimation of probable maximum precipitation (PMP) for a point or for an area is important in evaluating the hydrological impact of TCs. However, there is no such study for the coastal districts of India available in literature or in IMD/Central Water Commission, Government of India. IMD has calculated the daily point PMP vaues and published generalized maps for one day point PMP for the country (IMD 1988). It is based on 50-70 years of point rainfall data over the country. A combination of physical and statistical techniques has been used by IMD to develop these maps. Physical technique deals with the catchment characteristics and moisture holding capacity of the atmosphere. Statistical technique presumes the existence of an upper bound to the precipitation series and PMP is estimated by applying a suitable frequency analysis technique. The procedure followed by IMD is based on frequency analysis of the extreme rainfall time series, where the constants are evaluated on the basis of physical approach of storm maximization. 


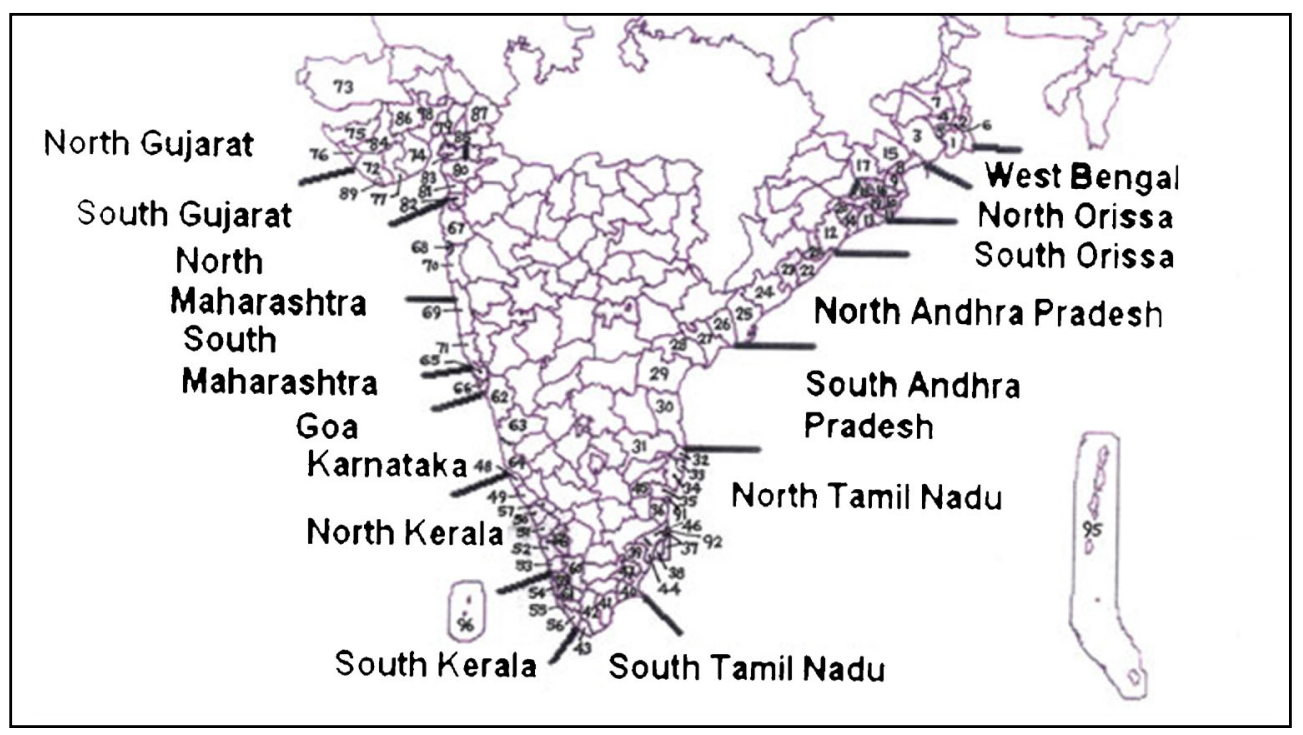

\begin{tabular}{|c|c|c|c|c|c|}
\hline \multirow{7}{*}{$\begin{array}{l}\text { West } \\
\text { Bengal }\end{array}$} & 1. South 24-Pargana(STP) & \multirow{15}{*}{$\begin{array}{l}\text { Tamil } \\
\text { Nadu (TN) }\end{array}$} & 33.Chennai(CNI) & \multirow{2}{*}{ Goa } & 65.North Goa \\
\hline & 2. North 24-Pargana & & 34.Kanchipuram(KCP) & & 66.South Goa \\
\hline & 3. Medinipur(MDP) & & 35.Viluppuram(VPM) & \multirow{5}{*}{ Maharashtra } & 67.Thane(TNE) \\
\hline & 4.Hoogly(HGL) & & 36.Cuddalore(CDL) & & 68.Mumbai (MMB) \\
\hline & 5.Howrah(HWR) & & 37.Nagappattinam(NPT) & & 69.Ratnagiri(RTN) \\
\hline & 6.Kolkata(CAL) & & 38.Tiruvarur(TVR) & & 70.Raigarh(RGD) \\
\hline & 7.Bardhaman(BDN) & & 39.Pudukkottai(PDK) & & 71.Sindhudurg(SDG) \\
\hline \multirow{14}{*}{ Odisha } & 8.Balasore(BLS) & & 40.Ramanathapuram(RMN) & \multirow{16}{*}{ Gujarat } & 72.Junagadh(JGH) \\
\hline & 9.Bhadrak(BDK) & & 41.Toothukudi(TTK) & & 73.Kachchh $(\mathrm{HCH})$ \\
\hline & 10.Kendrapara(KDP) & & 42.Tirunelveli(TNV) & & 74.Bhavnagar(BHV) \\
\hline & 11.Jagatsinghpur(JSP) & & 43.Kanyakumari(KYK) & & 75.Jamnagar(JMN) \\
\hline & 12.Ganjam(GJM) & & 44.ThanjavurTJR) & & 76.Porbandar(PBD) \\
\hline & 13.Puri(PRI) & & 45.Tiruvannamalai & & 77.Amreli(AML) \\
\hline & 14.Khordha(KRD) & & 46.Ariyalur & & 78.Ahmedabad(AHM) \\
\hline & 15.Mayurbhanj(MYB) & & 47.Sivaganga & & 79.Anand(AND) \\
\hline & 16. Jajpur(JJP) & & 48.Kasargod (KGD) & & 80. Surat (SRT) \\
\hline & 17.Keonjhar(KNJ) & \multirow{13}{*}{ Kerala } & 49.Kannur(KNN) & & 81.Navsari(NVS) \\
\hline & 18.Dhenkanal(DKL) & & 50.Kozhikode(KZK) & & 82.Valsad(VSD) \\
\hline & 19.Cuttack(CTK) & & 51.Malappuram(MLP) & & 83.Bharuch(BRC) \\
\hline & 20.Nayagarh(NYG) & & 52.Thrissur(TRS) & & 84.Rajkot(RJK) \\
\hline & 21.Gajapati (GJP) & & 53.Ernakulam(ERM) & & 85.Vadodara(VDD) \\
\hline \multirow{10}{*}{$\begin{array}{l}\text { Andhra } \\
\text { Pradesh } \\
\text { (AP) }\end{array}$} & 22.Srikakulam(SKM) & & 54.Alappuzha (ALP) & & 86.Surendra Nagar \\
\hline & 23.Vizianagaram(VJM) & & 55.Kollam(KLM) & & 87.Kheda (KDA) \\
\hline & 24.Visakhapatnam(VSK) & & 56.Thiruvananthapuram(TRV) & Daman \& & 88.Daman \\
\hline & 25.East Godavari(EDG) & & 57.Wayanad(WND) & Diu & 89.Diu \\
\hline & 26.West Godavari(WDG) & & 58.Palakkad(PKD) & $\begin{array}{l}\text { Dadra \& } \\
\text { Nagar Haveli }\end{array}$ & $\begin{array}{l}\text { 90.Dadra \& Nagar } \\
\text { Haveli }\end{array}$ \\
\hline & 27.Krishna(KSN) & & 59.Kottayam(KTM & \multirow{4}{*}{ Puducherry } & 91.Puducherry(PDC) \\
\hline & 28.Guntur(GNT) & & 60.Idukki(IDK) & & 92.Karaikal(KRK) \\
\hline & 29.Prakasam(PKM) & & 61.Pathanamthita(PMT) & & 93.Yanam(YNM) \\
\hline & 30.Nellore (NLR) & \multirow{3}{*}{ Karnataka } & 62.Uttar Kannada(UKD) & & 94.Mahe \\
\hline & 31.Chittor(CHR) & & 63.Udupi (UDP) & $\begin{array}{l}\text { A \& N } \\
\text { Islands }\end{array}$ & 95.A \& N Islands \\
\hline $\begin{array}{l}\text { Tamil } \\
\text { Nadu }\end{array}$ & 32.Tiruvallur(TVL) & & 64.Dakshin Kannada(DKD) & Lakshadweep & 96.Lakshadweep \\
\hline
\end{tabular}

Figure 1. Coastal districts of India within $100 \mathrm{~km}$ from the coast line.

Though there have been such studies on individual hazards as mentioned above, there have been few such studies to define any hazard index considering TC as a multi-hazard. Mohapatra et al. (2012) have analysed degree of cyclone hazard proneness of districts, based on the frequency and intensity of landfalling TCs along with all other hazards like rainfall, wind, and storm surge. The categorization of 96 districts under consideration indicates that $12,45,31$, and 8 districts are in very high, high, moderate and low categories of proneness, respectively. In general, the coastal districts of West Bengal, Odisha, Andhra Pradesh, and Tamil Nadu are more prone and are in the high to very 
high category. The TC hazard proneness factor is very high for the districts of Nellore, East Godawari and Krishna in Andhra Pradesh; Yanam in Puducherry; Balasore, Bhadrak, Kendrapara, and Jagatsinghpur in Orissa; and South and North 24-Parganas, Medinipur, and Kolkata in West Bengal. However, their study has considered actual/estimated wind speed over the district due to the TC. It has not considered the wind strength, which is responsible for the structural damage due to TC. Therefore, a study has been undertaken to analyse and determine TC hazard proneness of coastal districts of India based on the frequency and intensity of landfalling TCs along with all other hazards like rainfall, storm surge, and wind strength instead of wind speed.

\section{Data}

For the classification of districts based on TC hazard proneness, the districts considered in the study are the same as those considered by Mohapatra et al. (2012) and are shown in figure 1. It includes 72 districts touching the Indian seas and 24 districts close to the coast (within about $100 \mathrm{~km}$ from the coast) but not touching the sea.

The data on TCs for the period 1891-2010 have been collected from the electronic atlas of cyclonic disturbances published by IMD (2008). In this atlas, the TCs have been grouped in two categories,

Table 2. Categorization of districts based on the degree of proneness.

\begin{tabular}{ll}
\hline Category & Rating \\
\hline Low (P4) & $\leq 3.0$ \\
Moderate (P3) & $3.1-5.0$ \\
High (P2) & $5.1-7.0$ \\
Very high (P1) & $7.1-0.0$ \\
\hline
\end{tabular}

Table 3(i). Rating of districts based on total no. of severe cyclones crossing the district.

\begin{tabular}{lc}
\hline No. of severe cyclones & Rating \\
\hline $1-3$ & 3 \\
$4-6$ & 5 \\
$7-10$ & 7 \\
$>10$ & 10 \\
\hline
\end{tabular}

Table 3(ii). Rating of districts based on total number of cyclones crossing the district.

\begin{tabular}{lc}
\hline No. of cyclones & Rating \\
\hline $1-5$ & 3 \\
$6-10$ & 5 \\
$11-15$ & 7 \\
$>15$ & 10 \\
\hline
\end{tabular}

viz., (i) Cyclonic storms (CS) (MSW of 34-47 knots), and (ii) Severe cyclonic storms (SCS) and above categories (MSW $\geq 48$ knots). This categorization has been adopted for the study of hazardproneness of coastal districts of India as official data of IMD is available only in these two categories in the e-Atlas. The SCS includes very severe cyclonic storms (VSCS) and super cyclonic storms (SuCS) as well. To further consider the intensity of TCs, the frequency of VSCS and above intensity ( $\geq 64$ knots) has been considered during the period 1971-2010. The data on VSCS and above intensity are collected from articles published by IMD (1972-2011). Here the period of data has been restricted to 1971-2010, as the official data of IMD for this period only is available in published form.

While considering the data from e-Atlas of IMD to determine the districtwise frequency of TCs and severe TCs, such data available in earlier publications have been taken into consideration. Earlier published data on frequency of TCs include districtwise data published by IMD (2002) in 'Damage potential of cyclones', one-degree latitudewise data published in Vulnerability Atlas of BMTPC (2006) and 'Guidelines for management of cyclones' published by NDMA (2008) for the period 1877-2005. As the district has been considered as a unit in the present study, the frequency of TCs and severe TCs found in this study cannot be compared with those in Vulnerability Atlas of BMTPC (2006) and 'Guidelines for management of cyclones' (NDMA 2008). In Damage Potential of Cyclones published by IMD (2002), frequency of TCs and severe TCs correspond to old districts. However, frequency has been compared for the old districts and the sum of the frequencies of the districts carved out of the old district. This comparison shows that frequencies are in general agreement with each other except in

Table 3(iii). Rating of districts based on Probable Maximum Storm Surge (PMSS) over the district.

\begin{tabular}{lc}
\hline PMSS (metre) & Rating \\
\hline $0-2.0$ & 3 \\
$2.1-4.0$ & 5 \\
$4.1-6.0$ & 7 \\
$>6$ & 10 \\
\hline
\end{tabular}

Table 3(iv). Rating of districts based on Probable Maximum Precipitation (PMP) for a day in cms in the district.

\begin{tabular}{lc}
\hline PMP $(\mathrm{cm})$ & Rating \\
\hline $41-50$ & 3 \\
$51-60$ & 5 \\
$61-70$ & 7 \\
$>70$ & 10 \\
\hline
\end{tabular}


a few cases, as the source of the data is same in both the cases. The difference in a few cases arises due to the fact that (i) periods of data are different, (ii) the short lived TCs (with life period of $<1$ day) are not considered in the present study, as the statistics on these TCs are not included in the TC e-Atlas published by IMD (2008), and (iii) the TC crossing a coastal district after crossing another district has been considered for both the districts. For example, a northeastward recurving TC after crossing a coastal district of Andhra Pradesh may cross a coastal district of Odisha. Similarly, a west-northwestward moving cyclone crossing Bangladesh may cross 24 Pragana district of West Bengal with same intensity. Hence, these TCs, which do not cross 24 Pragana district, initially have been counted as TCs/severe TCs crossing these districts. The above principle has also been applied to calculate the number of TCs and severe TCs affecting interior coastal districts lying within $100 \mathrm{~km}$ from the coast, but not touching the coast.

\section{Methodology}

\subsection{TC parameters considered}

The frequencies of CS and SCS and hence total number of TCs crossing different coastal districts of the country during 1891-2010 have been tabulated. A district has been considered as TC prone if at least one $\mathrm{TC}$ in the past had crossed that district or the neighbouring one on both its sides during the period 1891-2010. As discussed earlier, the TC itself is a multi-hazard weather system. Therefore, only the frequency of landfalling TCs cannot determine the degree of proneness. Therefore to determine the degree of proneness, the following parameters have been considered.

(a) Total number of TCs crossing the district.

(b) Total no. of severe TCs crossing the district.

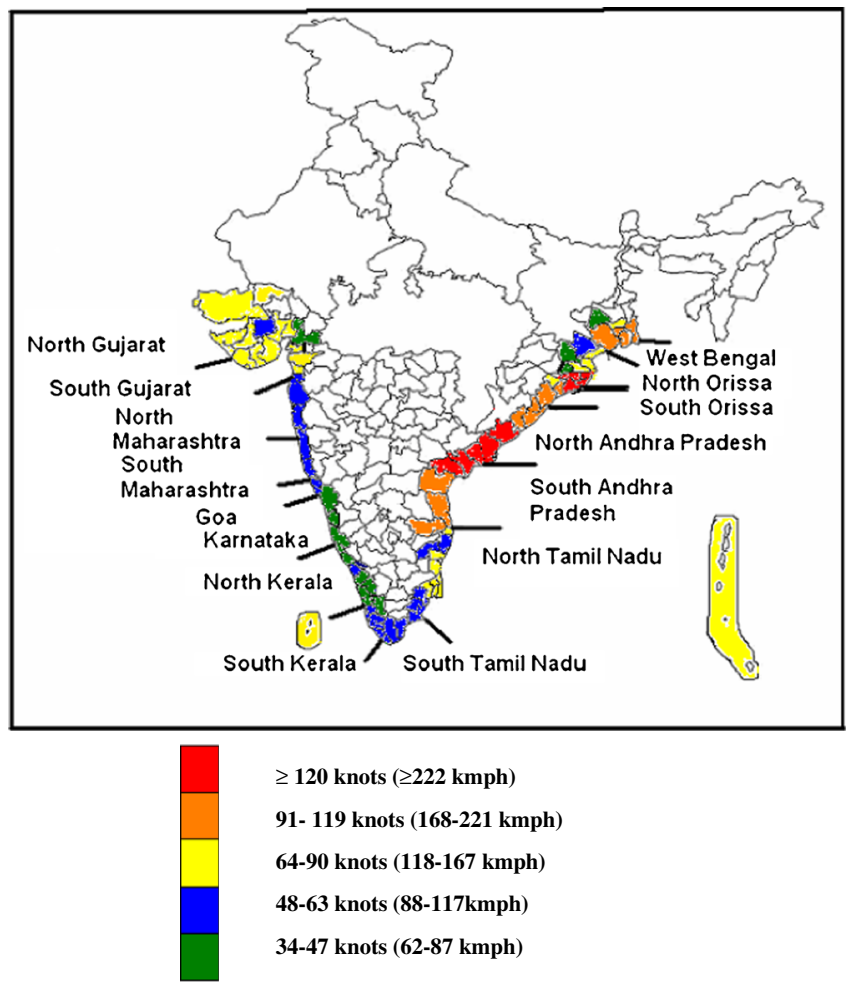

Figure 2. Maximum wind strength over districts of India based on actual/estimated maximum wind speed.

Table 3(v). Rating of districts based on wind strength.

\begin{tabular}{|c|c|c|c|c|c|}
\hline \multirow[b]{2}{*}{ Sl. no. } & \multirow{2}{*}{$\begin{array}{l}\text { Category } \\
\text { of TC }\end{array}$} & \multicolumn{2}{|c|}{ Wind speed } & \multirow{2}{*}{$\begin{array}{l}\text { Mid-value } \\
\quad(\mathrm{km})\end{array}$} & \multirow{2}{*}{$\begin{array}{l}\text { Ratings as per wind strength } \\
\quad(\text { Mid-value } / 222)^{2} \times 10\end{array}$} \\
\hline & & Knots & $\mathrm{KMPH}$ & & \\
\hline 1 & CS & $34-47$ & $62-87$ & 74.5 & $(74.5 / 222)^{2} \times 10=1.1 \simeq 1.0$ \\
\hline 2 & SCS & $48-63$ & $88-117$ & 102.5 & $(102.5 / 222)^{2} \times 10=2.1 \simeq 2.0$ \\
\hline 3 & VSCS & $64-90$ & $118-167$ & 142.5 & $(142.5 / 222)^{2} \times 10=4.1 \simeq 4.0$ \\
\hline 4 & VSCS & $91-119$ & $168-221$ & 194.5 & $(194.5 / 222)^{2} \times 10=7.6 \simeq 7.6$ \\
\hline 5 & $\mathrm{SuCS}$ & $\geq 120$ & $\geq 222$ & 222 & $(222 / 222)^{2} \times 10=10$ \\
\hline
\end{tabular}

Table 3(vi). Rating of districts based on wind strength, but with merger of VSCS (91-120 knots) and SuCS (12 knot or more).

\begin{tabular}{|c|c|c|c|c|c|}
\hline \multirow[b]{2}{*}{ Sl. no. } & \multirow{2}{*}{$\begin{array}{l}\text { Category } \\
\text { of cyclone }\end{array}$} & \multicolumn{2}{|c|}{ Wind speed } & \multirow{2}{*}{$\begin{array}{l}\text { Mid-value } \\
\qquad(\mathrm{km})\end{array}$} & \multirow{2}{*}{$\begin{array}{l}\text { Ratings as per wind strength } \\
\quad(\text { Mid-value } / 168)^{2} \times 10\end{array}$} \\
\hline & & Knots & $\mathrm{KMPH}$ & & \\
\hline 1 & CS & $34-47$ & $62-87$ & 74.5 & $(74.5 / 168)^{2} \times 10=1.97 \simeq 2$ \\
\hline 2 & SCS & $48-63$ & $88-117$ & 102.5 & $(102.5 / 168)^{2} \times 10=3.72 \simeq 4$ \\
\hline 3 & VSCS & $64-90$ & $118-167$ & 142.5 & $(142.5 / 168)^{2} \times 10=7.19 \simeq 7$ \\
\hline 4 & VSCS and SuCS & $\geq 91$ & $\geq 168$ & 168 & $(168 / 168)^{2} \times 10=10$ \\
\hline
\end{tabular}


(c) Probable maximum wind strength $\left(\mathrm{knot}^{2}\right)$ over the district based on actual/estimated MSW over the district.

(d) Probable maximum storm-surge (metre) over the district.

(e) Daily probable maximum precipitation $(\mathrm{cm})$ over any station in the district.

While the inputs for (a), (b) and (c) have been collected from officially published data of IMD, the inputs for (d) and (e) have been taken from the Vulnerability Atlas (BMTPC 2006) for which data source is again the publications of IMD. For the islands (Andaman \& Nicobar Islands and Lakshadweep Islands) probable maximum storm surge (PMSS) information is not available. Hence, the same has not been considered for these islands. The wind strength is proportional to the square of the wind speed. Hence, instead of taking wind speed into consideration, rating has been considered on the basis of the wind strength.

\subsection{Overall ratings}

For the purpose of deciding degree of proneness, different districts have been rated on a 10 point scale into four categories (table 2) based on the parameters mentioned in section 3.1. The criterion has been kept same as that used by Mohapatra et al.
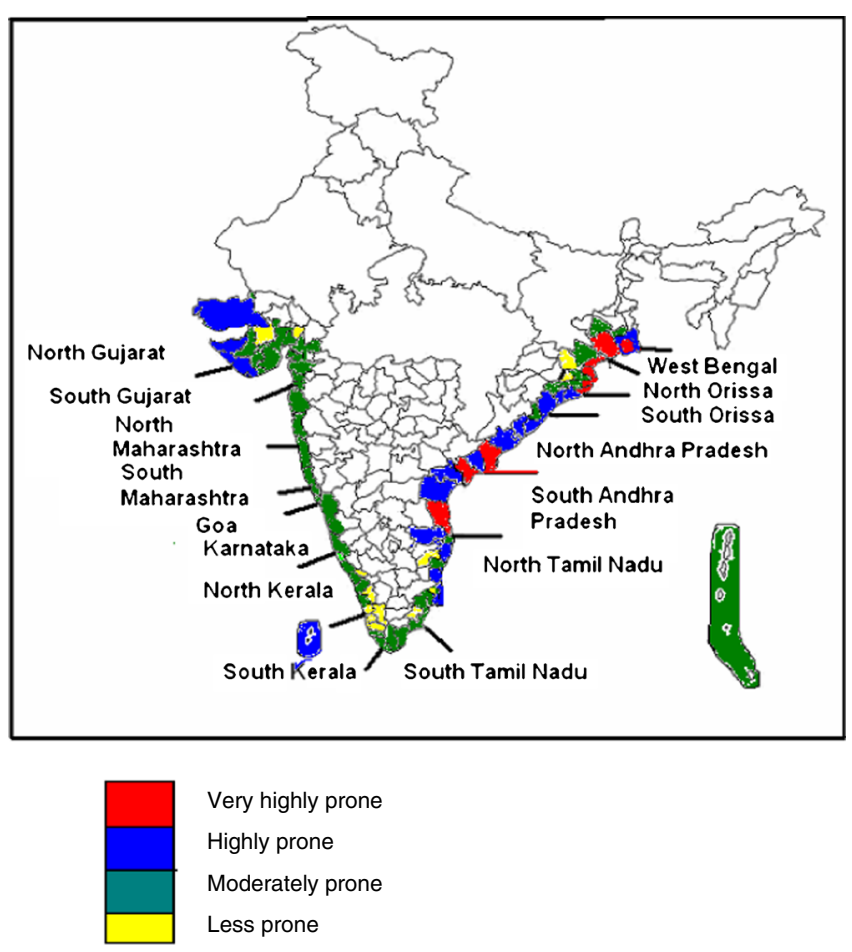

Very highly prone

Highly prone

Moderately prone

Less prone

Figure 3. TC hazard prone districts of India based on frequency of total cyclones, total severe cyclones, actual/estimated maximum wind strength with ratings of 1, 2, 4, 7.6 and 10; PMSS associated with the cyclone and PMP for all districts.
(2012) except for wind strength instead of wind speed so that results can be compared. For classification of TC hazard prone districts, a composite rating with a scale of $0-10$ as defined in table 2 has been adopted. Composite rating is divided into four groups of low, moderate, high, and very high categories. The composite rating has been calculated for individual districts using different weightages to various TC hazard parameters. Different ratings used for different TC parameters considered here are given in table 3. A TC is considered to have crossed a district, if it crossed the same district or its immediate neighbouring districts on both the sides along the coast. Based on this assumption, the frequency of TCs and severe TCs for each district have been calculated and the rating of a district has been made based on frequency of severe TCs and total TCs crossing the district as shown in table 3(i and ii). The frequencies of TCs and severe TCs have been categorized into four groups with the rating of $3,5,7$, and 10 . Similarly, the height of PMSS (table 3iii) and PMP (table 3iv) for a district have been categorized into four groups each with the same rating of $3,5,7$, and 10 . Though the rating parameters, viz., 3, 5, 7, and 10 are kept same for frequency of TCs, frequency of severe TCs, PMSS and PMP, the scale is nonlinear and is different for different TC parameters as can be seen from table 3 (vi).
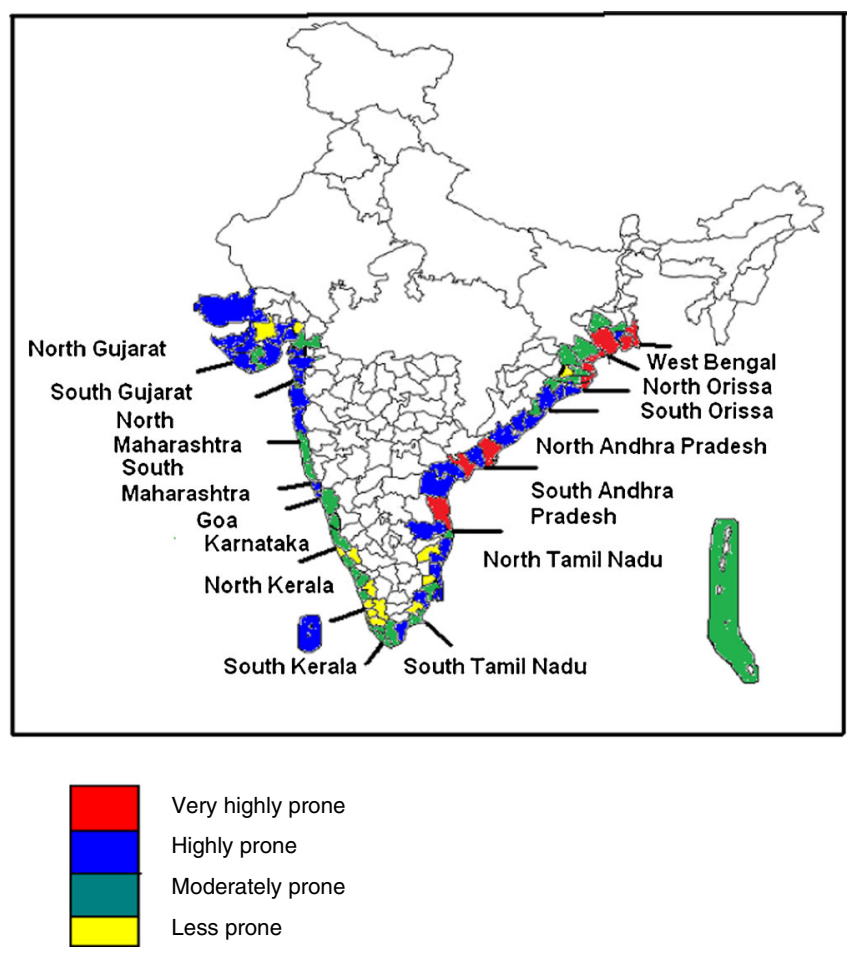

Very highly prone

Highly prone

Moderately prone

Less prone

Figure 4. Cyclone hazard prone districts of India based on frequency of total cyclones, total severe cyclones, actual/estimated maximum wind strength with ratings of 2 , 4, 7 and 10; PMSS associated with the cyclones and PMP for all districts. 
Table 4. Cyclone-prone districts of India touching the coast based on frequency of total cyclones and severe cyclones; strength of actual/estimated wind speed with rating of 2, 4, 7 and 10, PMSS and PMP for all districts.

\begin{tabular}{|c|c|c|c|c|c|c|c|c|}
\hline \multirow[b]{2}{*}{ State } & \multirow[b]{2}{*}{ Districts } & \multicolumn{5}{|c|}{ Ratings based on } & \multirow[b]{2}{*}{$\begin{array}{l}\text { Mean } \\
\text { rating }\end{array}$} & \multirow[b]{2}{*}{$\begin{array}{c}\text { Category of } \\
\text { proneness }\end{array}$} \\
\hline & & $\begin{array}{c}\text { No. of } \\
\text { severe } \\
\text { cyclones }\end{array}$ & $\begin{array}{l}\text { Total no. } \\
\text { of cyclones }\end{array}$ & $\begin{array}{l}\text { Strength of } \\
\text { wind speed }\end{array}$ & PMSS & PMP & & \\
\hline $\mathrm{AP}$ & Nellore & 7 & 10 & 10 & 7 & 7 & 8.2 & $\mathrm{P} 1$ \\
\hline $\mathrm{AP}$ & East Godavari & 5 & 10 & 10 & 7 & 7 & 7.8 & $\mathrm{P} 1$ \\
\hline $\mathrm{AP}$ & Krishna & 5 & 7 & 10 & 7 & 7 & 7.2 & $\mathrm{P} 1$ \\
\hline Odisha & Balasore & 5 & 10 & 7 & 10 & 7 & 7.8 & $\mathrm{P} 1$ \\
\hline Odisha & Kendrapara & 5 & 10 & 10 & 10 & 7 & 8.4 & $\mathrm{P} 1$ \\
\hline Odisha & Jagatsinghpur & 5 & 10 & 10 & 10 & 7 & 8.4 & $\mathrm{P} 1$ \\
\hline Odisha & Bhadrak & 5 & 10 & 7 & 10 & 7 & 7.8 & $\mathrm{P} 1$ \\
\hline Puducherry & Yanam & 5 & 10 & 10 & 7 & 7 & 7.8 & $\mathrm{P} 1$ \\
\hline West Bengal & South 24-Pragana & 10 & 10 & 10 & 10 & 7 & 9.4 & $\mathrm{P} 1$ \\
\hline West Bengal & Medinipur & 7 & 10 & 10 & 10 & 7 & 8.8 & $\mathrm{P} 1$ \\
\hline $\mathrm{AP}$ & Srikakulam & 5 & 7 & 10 & 5 & 7 & 6.8 & $\mathrm{P} 2$ \\
\hline $\mathrm{AP}$ & Guntur & 3 & 3 & 10 & 10 & 7 & 6.6 & $\mathrm{P} 2$ \\
\hline $\mathrm{AP}$ & Visakhapatnam & 5 & 5 & 10 & 5 & 7 & 6.4 & $\mathrm{P} 2$ \\
\hline $\mathrm{AP}$ & West Godavari & 3 & 5 & 10 & 7 & 7 & 6.4 & $\mathrm{P} 2$ \\
\hline $\mathrm{AP}$ & Prakasam & 3 & 3 & 10 & 7 & 7 & 6 & $\mathrm{P} 2$ \\
\hline $\mathrm{AP}$ & Vizianagaram & 3 & 3 & 10 & 5 & 7 & 5.6 & $\mathrm{P} 2$ \\
\hline Daman \& Diu & Diu & 5 & 5 & 7 & 5 & 10 & 6.4 & $\mathrm{P} 2$ \\
\hline Daman \& Diu & Daman & 3 & 3 & 4 & 7 & 10 & 5.4 & $\mathrm{P} 2$ \\
\hline Goa & North Goa & 3 & 3 & 4 & 7 & 10 & 5.4 & $\mathrm{P} 2$ \\
\hline Goa & South Goa & 3 & 3 & 4 & 7 & 10 & 5.4 & $\mathrm{P} 2$ \\
\hline Gujarat & Junagadh & 5 & 5 & 7 & 5 & 10 & 6.4 & $\mathrm{P} 2$ \\
\hline Gujarat & Ahmedabad & 3 & 3 & 7 & 7 & 7 & 5.4 & P2 \\
\hline Gujarat & Kachchh & 5 & 5 & 7 & 5 & 7 & 5.4 & $\mathrm{P} 2$ \\
\hline Gujarat & Bhavnagar & 3 & 3 & 7 & 7 & 7 & 5.4 & $\mathrm{P} 2$ \\
\hline Gujarat & Jamnagar & 3 & 5 & 7 & 5 & 10 & 6.0 & $\mathrm{P} 2$ \\
\hline Gujarat & Anand & 3 & 3 & 7 & 7 & 7 & 5.4 & $\mathrm{P} 2$ \\
\hline Gujarat & Navsari & 0 & 3 & 7 & 7 & 10 & 5.4 & $\mathrm{P} 2$ \\
\hline Gujarat & Surat & 0 & 3 & 7 & 7 & 10 & 5.4 & P2 \\
\hline Gujarat & Bharuch & 0 & 3 & 7 & 7 & 10 & 5.4 & $\mathrm{P} 2$ \\
\hline Gujarat & Valsad & 3 & 3 & 4 & 7 & 10 & 5.4 & $\mathrm{P} 2$ \\
\hline Gujarat & Rajkot & 3 & 3 & 7 & 5 & 10 & 5.6 & $\mathrm{P} 2$ \\
\hline Gujarat & Porbandar & 3 & 3 & 7 & 5 & 10 & 5.6 & $\mathrm{P} 2$ \\
\hline Lakshadweep & Lakshadweep & 5 & 5 & 7 & 0 & 10 & 5.4 & $\mathrm{P} 2$ \\
\hline Maharashtra & Thane & 3 & 3 & 4 & 7 & 10 & 5.4 & $\mathrm{P} 2$ \\
\hline Maharashtra & Mumbai suburban & 3 & 3 & 4 & 7 & 10 & 5.4 & $\mathrm{P} 2$ \\
\hline Maharashtra & Raigarh & 3 & 3 & 4 & 7 & 10 & 5.4 & $\mathrm{P} 2$ \\
\hline Odisha & Ganjam & 5 & 7 & 10 & 5 & 5 & 6.4 & $\mathrm{P} 2$ \\
\hline Odisha & Puri & 3 & 5 & 10 & 5 & 7 & 6 & $\mathrm{P} 2$ \\
\hline Odisha & Khordha & 3 & 3 & 10 & 5 & 7 & 5.6 & $\mathrm{P} 2$ \\
\hline Puducherry & Karaikal & 3 & 5 & 7 & 7 & 7 & 5.8 & $\mathrm{P} 2$ \\
\hline Puducherry & Puducherry & 3 & 3 & 7 & 5 & 10 & 5.6 & $\mathrm{P} 2$ \\
\hline Tamil Nadu & Pudukkottai & 3 & 3 & 4 & 10 & 7 & 5.4 & $\mathrm{P} 2$ \\
\hline Tamil Nadu & Cuddalore & 5 & 5 & 7 & 5 & 10 & 6.4 & $\mathrm{P} 2$ \\
\hline Tamil Nadu & Kanchipuram & 7 & 7 & 4 & 5 & 10 & 6.6 & $\mathrm{P} 2$ \\
\hline Tamil Nadu & Tiruvarur & 3 & 5 & 7 & 7 & 7 & 5.8 & $\mathrm{P} 2$ \\
\hline Tamil Nadu & Nagappattinam & 3 & 5 & 7 & 7 & 10 & 6.4 & $\mathrm{P} 2$ \\
\hline Tamil Nadu & Chennai & 3 & 3 & 10 & 5 & 7 & 5.6 & $\mathrm{P} 2$ \\
\hline Tamil Nadu & Thoothukudi & 3 & 3 & 4 & 10 & 7 & 5.4 & $\mathrm{P} 2$ \\
\hline Tamil Nadu & Viluppuram & 3 & 3 & 7 & 5 & 10 & 5.6 & $\mathrm{P} 2$ \\
\hline A\&N Island & A\&N Islands & 3 & 5 & 7 & - & - & 5 & P3 \\
\hline Gujarat & Vadodara & 3 & 3 & 2 & 7 & 10 & 5 & P3 \\
\hline
\end{tabular}


Table 4. (Continued.)

\begin{tabular}{|c|c|c|c|c|c|c|c|c|}
\hline \multirow[b]{2}{*}{ State } & \multirow[b]{2}{*}{ Districts } & \multicolumn{5}{|c|}{ Ratings based on } & \multirow[b]{2}{*}{$\begin{array}{l}\text { Mean } \\
\text { rating }\end{array}$} & \multirow[b]{2}{*}{$\begin{array}{c}\text { Category of } \\
\text { proneness }\end{array}$} \\
\hline & & $\begin{array}{c}\text { No. of } \\
\text { severe } \\
\text { cyclones }\end{array}$ & $\begin{array}{l}\text { Total no. } \\
\text { of cyclones }\end{array}$ & $\begin{array}{l}\text { Strength of } \\
\text { wind speed }\end{array}$ & PMSS & PMP & & \\
\hline Gujarat & Amreli & 3 & 3 & 7 & 5 & 7 & 5 & P3 \\
\hline Karnataka & Udupi & 0 & 3 & 2 & 7 & 10 & 4.4 & P3 \\
\hline Karnataka & Uttar Kannada & 0 & 3 & 2 & 7 & 10 & 4.4 & P3 \\
\hline Karnataka & Dakshin Kannada & 0 & 3 & 2 & 7 & 10 & 4.4 & P3 \\
\hline Kerala & Kozhikode & 3 & 3 & 4 & 7 & 7 & 4.8 & P3 \\
\hline Kerala & Malappuram & 3 & 3 & 2 & 7 & 7 & 4.4 & P3 \\
\hline Kerala & Thrissur & 0 & 3 & 2 & 7 & 7 & 3.8 & P3 \\
\hline Kerala & Kannur & 3 & 3 & 2 & 5 & 7 & 4 & P3 \\
\hline Kerala & Kollam & 0 & 3 & 4 & 5 & 5 & 3.4 & P3 \\
\hline Kerala & Alappuzha & 3 & 3 & 4 & 5 & 3 & 3.6 & P3 \\
\hline Kerala & Thiruvananthapuram & 3 & 3 & 4 & 5 & 5 & 4.0 & P3 \\
\hline Maharashtra & Ratnagiri & 3 & 3 & 4 & 5 & 10 & 5 & P3 \\
\hline Maharashtra & Sindhudurg & 3 & 3 & 4 & 5 & 10 & 5 & P3 \\
\hline Puducherry & Mahe & 3 & 3 & 4 & 7 & 7 & 4.8 & P3 \\
\hline Tamil Nadu & Ramanathapuram & 3 & 3 & 4 & 10 & 5 & 5 & P3 \\
\hline Tamil Nadu & Tirunelveli & 3 & 3 & 4 & 10 & 5 & 5 & P3 \\
\hline Tamil Nadu & Thanjavur & 3 & 3 & 7 & 7 & 5 & 5 & P3 \\
\hline Tamil Nadu & Tiruvallur & 3 & 3 & 7 & 5 & 7 & 5 & P3 \\
\hline Tamil Nadu & Kanyakumari & 3 & 3 & 4 & 5 & 3 & 3.6 & P3 \\
\hline Kerala & Kasargod & 0 & 3 & 2 & 5 & 5 & 3 & $\mathrm{P} 4$ \\
\hline \multirow[t]{2}{*}{ Kerala } & Ernakulam & 0 & 3 & 2 & 5 & 5 & 3 & $\mathrm{P} 4$ \\
\hline & Total & \multicolumn{7}{|c|}{72} \\
\hline
\end{tabular}

For the purpose of rating, the mid-value of the MSW corresponding to different categories of TCs (table 1) has been calculated. The threshold wind speed of $222 \mathrm{kmph}$ (120 knots) has been considered as the mid-value for the category of SuCS. Assigning the maximum rating of 10 to wind strength in association with SuCS, relative rating of wind strength has been calculated for wind strength associated with other categories of TCs. The detailed method is demonstrated in table $3(\mathrm{v})$.

Accordingly, the composite rating of each district is calculated based on the simple arithmetic mean of rating of five TC parameters including frequency of total TCs, frequency of total severe TCs, PMP, PMSS, and actual/estimated wind strength.

As a second approach, the categories of VSCS (MSW of 91-120 knot) and SuCS (MSW of 120 knots or more) are merged into one category, as in the procedure followed by Mohapatra et al. (2012), keeping other parameters same as discussed above. Thus the wind speeds of 91-119 knots and 120 knots or more in association with the VSCS and SuCS have been considered as one category and given the same weight of 10 for the calculation of rating of districts based on wind strength in a second attempt to classify the districts. Therefore, the maximum wind of $168 \mathrm{kmph}$ (91 knots) has been considered instead of $222 \mathrm{kmph}(120$ knots) as discussed earlier for calculation of relative wind strength. Accordingly, the wind strength and rating have been calculated as given in table 3 (vi).

The above method of classification of cyclone hazard prone districts and the methods adopted by Mohapatra et al. (2012) do not take into consideration directly the percentage fraction of total TCs crossing a district as SCS, though it considers frequency of SCS. Hence, the rate of intensification instead of actual frequency of SCS has also been examined. This fraction has been multiplied with the rating obtained from the total number of TCs crossing the district. Then, there are ratings of four parameters, viz. total frequency of TCs crossing/affecting the district weighted by the fraction of CS crossing as SCS, actual/estimated maximum wind strengh, PMP, and PMSS. Composite rating is calculated by taking the simple average of the four ratings.

\section{Results and discussion}

4.1 Hazard proneness based on frequency of severe TCs ( $\geq 48$ knots), total TCs ( $\geq 34$ knots) and actual/estimated maximum wind strengh, PMP and PMSS

The categorisation of districts based on the procedure as discussed in the previous section with wind strength rating of $1,2,4,7.6$, and 10 (table $3 \mathrm{v}$ ) 
coreresponding to CS, SCS, VSCS (MSW of 64-90 knots), VSCS (91-120 knots), and SuCS respectively is shown in figure 2. The composite rating based on the above classification of wind strength along with classification based on frequency of severe TCs and total TCs, PMSS, and PMP as defined in table 3 has been calculated for each district. The results are shown in figure 3. The analysis in the above method led to inconsistent results. The coastal districts in Maharashtra and Gujarat could not be differentiated and were put under the same category of proneness, though it is a fact that the coastal districts of Gujarat are more prone than those of Maharashtra.

4.2 Hazard proneness based on frequency of severe TCs ( $\geq 48$ knots), total TCs ( $\geq 34$ knots), PMP, $P M S S$ and actual/estimated maximum wind strengh but with merger of VSCS (MSW of 91-120 knots) and SUCS categories

The wind speeds of 91-119 knots and 120 knots or more in association with the VSCS and SuCS have been considered as one category and given the same weight of 10 . Accordingly, the wind strength and rating have been calculated. The ratings are 2 , 4, 7, and 10 with respect to CS, SCS, VSCS (MSW of 64-90 knots), and VSCS/SuCS (MSW of 91 knots or more). The results are depicted in figure 4 and tables $4-5$. It is found that it resulted in better findings compared to figure 3 . It could distinguish the proneness of west coast districts. Further, considering the strength of wind in place of actual/estimated maximum wind, there are a few changes in proneness of the districts along east coast.

Comparing figure 4 with figure 5 (Mohapatra et al. 2012) based on actual/estimated wind speed, the classification of districts presented in figure 4 seems to be more logical. The higher proneness is distinguishable for the districts of north Tamil Nadu and Puducherry from the lower proneness of south Tamil Nadu districts unlike in figure 5 . This classification also distinguishes the proneness of districts in Gujarat, Konkan, Karnataka, and Kerala coasts in a better manner compared to that presented in figure 5 as it distinguishes the highly prone districts of Gujarat and north

Table 5. Cyclone prone districts of India not touching the coast based on frequency of total cyclones and severe cyclones; strength of actual/estimated wind speed with rating of 2, 4, 7 and 10, PMSS and PMP for all districts.

\begin{tabular}{|c|c|c|c|c|c|c|c|c|}
\hline \multirow[b]{2}{*}{ State } & \multirow[b]{2}{*}{ Districts } & \multicolumn{5}{|c|}{ Ratings based on } & \multirow[b]{2}{*}{$\begin{array}{l}\text { Mean } \\
\text { rating }\end{array}$} & \multirow[b]{2}{*}{$\begin{array}{c}\text { Category of } \\
\text { proneness }\end{array}$} \\
\hline & & $\begin{array}{c}\text { No. of } \\
\text { severe } \\
\text { cyclones }\end{array}$ & $\begin{array}{l}\text { Total no. } \\
\text { of cyclones }\end{array}$ & $\begin{array}{l}\text { Strength of } \\
\text { wind speed }\end{array}$ & PMSS & PMP & & \\
\hline West Bengal & North 24-Pragana & 10 & 10 & 10 & 0 & 7 & 7.4 & $\mathrm{P} 1$ \\
\hline West Bengal & Kolkata & 10 & 10 & 10 & 0 & 7 & 7.4 & $\mathrm{P} 1$ \\
\hline $\mathrm{AP}$ & Chittor & 7 & 7 & 10 & 0 & 7 & 6.2 & $\mathrm{P} 2$ \\
\hline West Bengal & Howrah & 10 & 10 & 10 & 0 & 5 & 7 & $\mathrm{P} 2$ \\
\hline Dadra \& Nagar Haveli & Dadra \& Nagar Haveli & 3 & 3 & 4 & 0 & 10 & 4 & P3 \\
\hline Odisha & Mayurbhanj & 3 & 7 & 4 & 0 & 7 & 4.2 & P3 \\
\hline Odisha & Cuttack & 3 & 3 & 10 & 0 & 7 & 4.6 & P3 \\
\hline Odisha & Nayagarh & 3 & 5 & 7 & 0 & 7 & 4.4 & P3 \\
\hline Odisha & Gajapati & 3 & 3 & 10 & 0 & 7 & 4.6 & P3 \\
\hline Odisha & Jajpur & 3 & 3 & 7 & 0 & 7 & 4 & P3 \\
\hline Odisha & Keonjhar & 3 & 3 & 2 & 0 & 7 & 3 & P3 \\
\hline West Bengal & Hoogly & 3 & 7 & 7 & 0 & 7 & 4.8 & P3 \\
\hline West Bengal & Bardhaman & 3 & 5 & 2 & 0 & 7 & 3.4 & P3 \\
\hline Gujarat & Surendra Nagar & 3 & 3 & 4 & 0 & 5 & 3 & $\mathrm{P} 4$ \\
\hline Gujarat & Kheda & 3 & 3 & 2 & 0 & 5 & 2.6 & $\mathrm{P} 4$ \\
\hline Kerala & Wayand & 3 & 3 & 4 & 0 & 5 & 3 & $\mathrm{P} 4$ \\
\hline Kerala & Palakkad & 0 & 3 & 2 & 0 & 5 & 2.0 & $\mathrm{P} 4$ \\
\hline Kerala & Kottayam & 3 & 3 & 2 & 0 & 5 & 2.6 & $\mathrm{P} 4$ \\
\hline Kerala & Idukki & 3 & 3 & 2 & 0 & 5 & 2.6 & $\mathrm{P} 4$ \\
\hline Kerala & Pathanamthita & 3 & 3 & 2 & 0 & 5 & 2.6 & $\mathrm{P} 4$ \\
\hline Odisha & Dhenkanal & 3 & 3 & 2 & 0 & 5 & 2.6 & $\mathrm{P} 4$ \\
\hline Tamil Nadu & Ariyalur & 3 & 3 & 2 & 0 & 7 & 3 & $\mathrm{P} 4$ \\
\hline Tamil Nadu & Tiruvannamalai & 3 & 3 & 4 & 0 & 3 & 2.6 & $\mathrm{P} 4$ \\
\hline Tamil Nadu & Sivaganga & 3 & 3 & 4 & 0 & 3 & 2.6 & $\mathrm{P} 4$ \\
\hline \multicolumn{2}{|c|}{ Total } & \multicolumn{7}{|c|}{24} \\
\hline
\end{tabular}



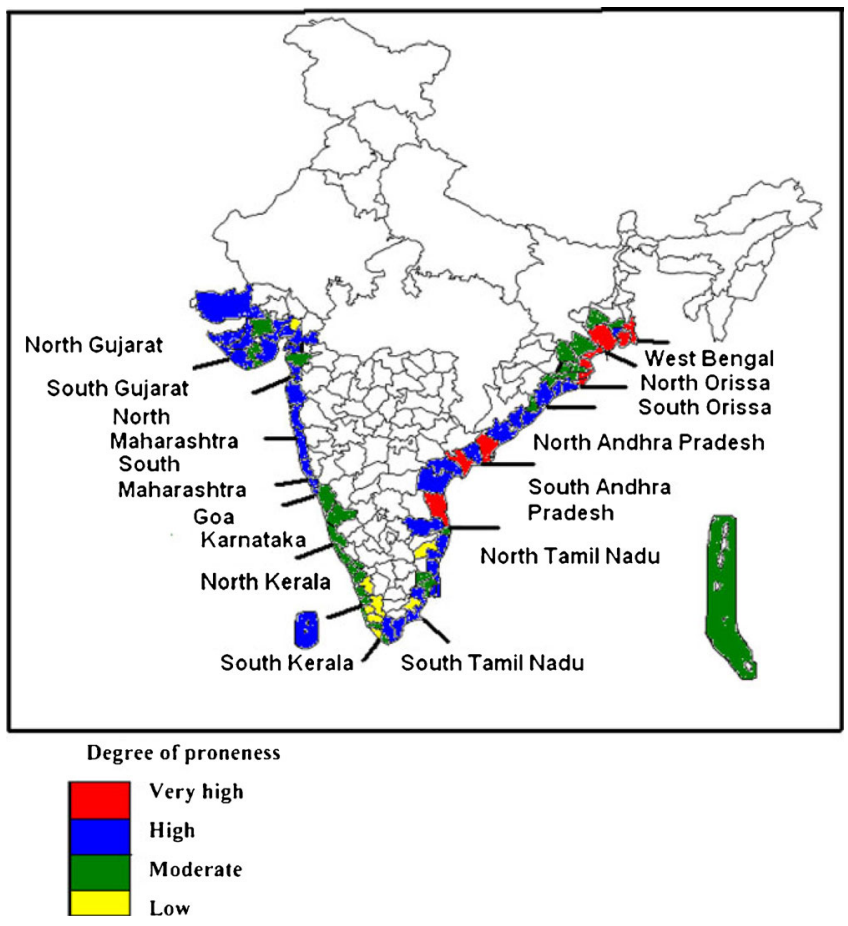

Figure 5. Cyclone hazard prone districts of India based on frequency of total cyclones, total severe cyclones, actual/estimated maximum wind, PMSS associated with the cyclones and PMP for all districts (Mohapatra et al. 2012).

Maharashtra from moderately prone districts of south Maharashtra. Further, it distinguishes the highly prone districts of Goa from moderately prone districts of Karnataka and south Maharashtra and distinguishes the moderately prone and less prone districts of Kerala.

4.3 Hazard proneness based on frequency of total $T C s$ ( $\geq 34$ knots), fraction of TCs landfalling as severe TCs instead of frequency of SCS, actual/ estimated maximum wind strengh, PMP with higher threshold and PMSS

The results of the analysis on hazard proneness based on frequency of total TCs ( $\geq 34$ knots), fraction of TCs landfalling as severe TCs, actual/estimated maximum wind strengh, PMP, and PMSS are presented in figure 6. In this method, the weight given to the districts, where there is no severe TC, decreases as the factor becomes zero. Also, it is difficult to calculate the factor for the districts with both zero severe TCs and zero total TCs. The results thus obtained become inconsistent and difficult to explain. Highly prone districts like North 24-Pragana becomes moderately prone. It fails to distinguish the more prone districts of Andhra Pradesh, which have experienced SuCS in the past. Hence this classification is not accepted.

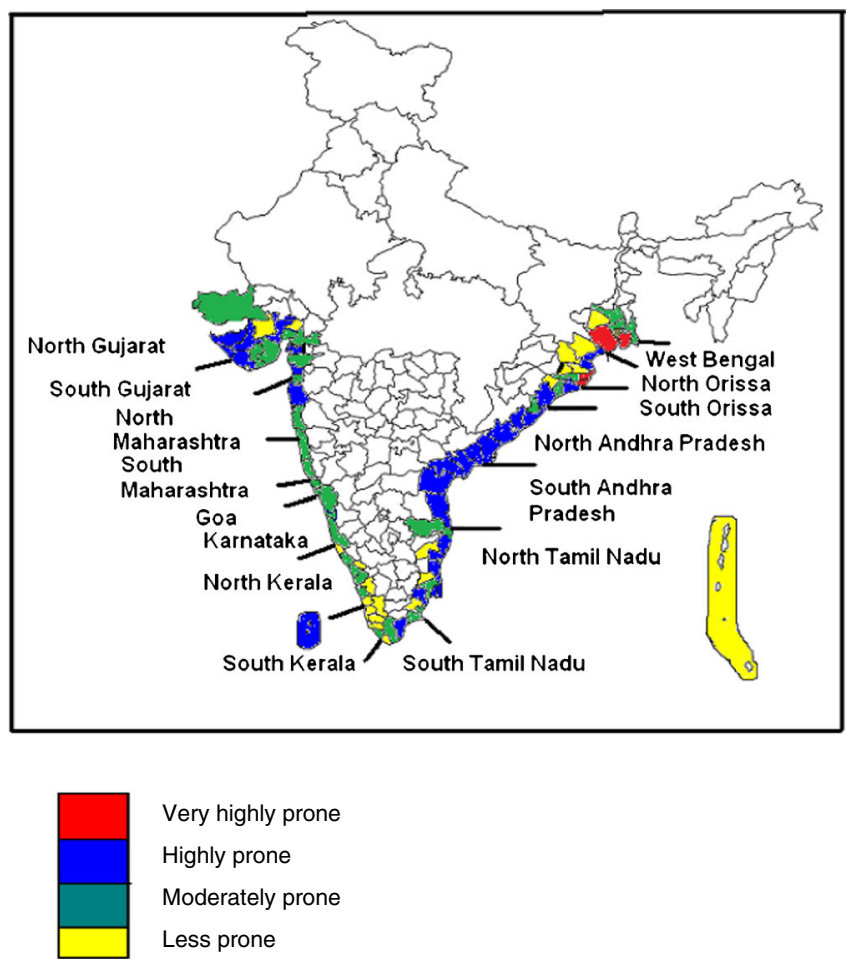

Figure 6. Cyclone hazard prone districts of India based on frequency of total cyclones, fraction of cyclones crossing as severe cyclones, actual/estimated maximum wind strength; PMSS associated with the cyclones and PMP for all districts.

\section{Conclusions and future scope}

(i) The results as shown in figure 4 give a realistic picture of the degree of cyclone hazard proneness of districts, as they represent the frequency and intensity of landfalling TCs along with all other hazards like rainfall, wind and storm surge. It takes into consideration the frequency of total TCs, frequency of total severe TCs, wind strength, PMSS, and PMP to cause damage due to TC. The categorization of districts with degree of proneness also tallies with observed pictures. Therefore, it is proposed that this classification of coastal districts based on hazards (tables 4-5/figure 4) may be considered for a TC hazard analysis.

(ii) Ninety-six districts including 72 districts touching the coast and 24 districts not touching the coast, but lying within $100 \mathrm{~km}$ from the coast have been classified based on their proneness. Out of 96 districts, 12 are very highly prone, 41 are highly prone, 30 are moderately prone, and the remaining 13 are less prone. Twelve very highly prone districts include South and North 24 Praganas, Medinipur, and Kolkata of West Bengal, Balasore, Bhadrak, Kendrapara, and Jagatsinghpur districts of Odisha, Nellore, Krishna, and east Godavari districts of Andhra Pradesh 
and Yanam of Puducherry. The remaining districts of Odisha and Andhra Pradesh, which touch the coast are highly prone districts. The north Tamil Nadu coastal districts are more prone than the south Tamil Nadu districts (south of about $10^{\circ} \mathrm{N}$ latitude). Most of the coastal districts of Gujarat and north Konkan are also highly prone districts. The remaining districts in the west coast and south Tamil Nadu are either moderately prone or less prone districts.

(iii) This classification is only based on hazard criteria. Vulnerability of the place has not been taken into consideration. Therefore, composite cyclone risk of a district, which is the product of hazard and vulnerability, needs to be assessed separately through detailed study. Such an initiative is being taken by NDMA through the World Bank assisted National Cyclone Risk Mitigation Project (NCRMP).

(iv) The MSW indicated against a district in this report is the 3-min average wind speed normally recorded by IMD. Keeping in mind that it is the 3-second peak-gust wind speed that is usually adopted for design of buildings and structures (Lakshmanan et al. 2009), the MSW indicated against the districts (Mohapatra et al. 2012) need to be multiplied by an appropriate factor for design of all buildings and structures in general and for the design of the post-disaster service structures (such as cyclone shelters, hospitals, transmission lines and communication towers, schools, etc.), in particular.

(v) In this list of cyclone hazard prone districts of the country, some of the districts of northeast India appearing in the list prepared by BMTPC have not appeared. This is because those districts are away from the coast and no parts of these districts were affected by storm surge requiring large scale evacuation of population. Floods due to cyclones over these districts are also very rare. These districts are mostly affected by depressions. Also interior districts of coastal states were not considered though some of these may be affected by storm wind and very high rainfall causing damage and destruction to life and properties.

(vi) The analysis is based on the estimation of daily point PMP by IMD. The criteria adopted for categorization of PMP is arbitrary and subjective. However, IMD and Central Water Commission are developing a new PMP atlas based on longer and latest data. The PMP atlas needs to be prepared considering the actual extreme rainfall over the districts due to TCs only. There is scope for reanalysis of TC hazard proneness based on PMP of districts in association with TCs.

(vii) The wind data in association with TC is based on the period of 1971-2010. It is mainly based on the wind estimated by Dvorak's technique (Dvorak 1984) and post-cyclone survey report along with the coastal observations available from IMD's observational network. There is further scope for improvement in estimation of TC wind hazard with upgradation of observational network with high wind speed recorder (HWSR), Doppler Weather Radar and validation of Dvorak's technique based on instrumented aircraft observation from the core and periphery of the TC.

(viii) The study is based on the residual storm surge height in association with the TC crossing coast. It does not take into consideration the total water envelope due to astronomical tide, in-shore current, river discharge, and heavy rainfall distribution, etc. All these factors can influence the storm surge and hence resultant tidal wave. Therefore, there is further scope to estimate the storm surge hazard based on total water envelope and coastal inundation and hence to modify the hazard proneness of the coastal districts. Studies are in progess by various researchers including those from Indian National Centre for Ocean Information Services (INCOIS), Hyderabad and Centre for Atmospheric Sciences, Indian Institute of Technology (IIT), Delhi to develop the models for total water envelope and coastal inundation due to landfall of TC.

(ix) The factors such as probable maximum wind strength, PMSS, and daily PMP are used to determine the degree of proneness based on the observed datasets. However, if speed and the size of the storm varies, then it is going to have an impact on all the aforementioned factors based on maximum duration of the wind strength/rainfall/storm surge and maximum area (size) to be impacted by the landfalling TC. Hence, the degree of proneness may vary in such conditions.

\section{Acknowledgements}

The author is thankful to National Disaster Management Authority and India Meteorological Department for giving the opportunity to carry out this work. The author also thanks Shri B Bhattacharjee, Hon'ble Member, NDMA, AVM (Dr) Ajit Tyagi, Ex-Director General of Meteorology, IMD, Dr L S Rathore, Director General of 
Meteorology, IMD, and Shri B K Bandyopadhyay, Deputy Director General of Meteorology (Services), IMD, for useful suggestions and advice.

The author also acknowledges all the reviewers for their comments and suggestions for the completion of work. He is thankful to those experts, including Dr S Arunachalam, Advisor, SERC, Chennai, who have provided valuable comments for the modification of this document. He thanks IMD and BMTPC for making available the required data for the work. He is grateful to Cyclone Warning Division of IMD, especially Shri D P Nayak, Shri R P Sharma, Smt Monica Sharma, and Shri S V J Kumar, for data collection and technical support for this work.

\section{References}

BMTPC 2006 Vulnerability Atlas of India: Earthquake, windstorm and flood hazard maps and damage risk to housing; Building Materials \& Technology Promotion Council; Ministry of Housing \& Urban Poverty Alleviation, Government of India.

Dube S K, Poulose Jisme and Rao A D 2013 Numerical simulation of storm surge associated with severe cyclonic storm in the Bay of Bengal during 2008-2011; Monsoon 64 193-202.

Dvorak V F 1984 Tropical cyclone intensity analysis using satellite data; NOAA Tech Report, 11, 45p.
IMD 1972-2011 Cyclones and depressions over north Indian Ocean; Mausam, Vol. 26-62.

IMD 1988 Generalised maps of 1-day point probable maximum precipitation; Meteorological Monograph, Hydrology/No. 11/1988, pp. 1-8.

IMD 2002 Damage potential of tropical cyclones; IMD, Pune, pp. 1-29.

IMD 2008 Tracks of Cyclones and Depressions (1891-2007); Electronic Version 1.0/2008, IMD, Chennai-6.

IMD 2013 Cyclone Warning in India: Standard Operation Procedure, IMD, New Delhi.

IS: 875 (Part 3-1987) 1989 India Standard Code of practice for design of loads (other than earthquakes) for buildings and structures, part 3 (wind loads); Bureau of Indian Standards, New Delhi.

Kalsi S R, Jayanthi N, Raj Y E A and Roy Bhowmik S K 2007 Probable maximum storm surge heights for the maritime districts of India; Met. Monograph No. Synoptic meteorology-5/2007, IMD, New Delhi.

Lakshmanan N, Gomathinayagam S, Harikrishna P, Abraham A and Chitra Ganapathi S 2009 Basic wind speed map of India with long-term hourly wind data; Curr. Sci. 96 911-922.

Mohapatra M, Mandal G S, Bandyopadhyay B K, Ajit Tyagi and Mohanty U C 2012 Classification of cyclone hazard prone districts of India; Natural Hazards 63 1601-1620.

NDMA 2008 'National Disaster Management Guidelines: Management of Cyclones', NDMA, Govt. of India, Safdarjang Enclave, New Delhi.

WMO 2009 Tropical cyclone operational plan for the Bay of Bengal and the Arabian Sea; Tropical Cyclone Programme Report no. TCP-21 Edition 2009, WMO/TD No. 84 . 